\title{
The health case for urgent action on climate change
}

\author{
Health professionals have a leading role
}

\author{
Andy Haines, professor \\ Pauline Scheelbeek, assistant professor \\ Centre on Climate Change and Planetary Health, \\ London School of Hygiene and Tropical Medicine, \\ London, UK \\ Correspondence to: A Haines \\ Andy.Haines@lshtm.ac.uk
}

It is about 30 years since warnings first appeared in prominent journals about the potential for large and wide ranging effects on human health from climate and other global environmental changes. ${ }^{1-3}$ To date, global action to tackle these burgeoning threats remains inadequate both in scale and in speed. For example, the pledged nationally determined contributions to reducing greenhouse gas emissions-as enshrined in the 2015 Paris Agreement on Climate Change-are a first step, but even if fully implemented (and this is by no means certain), global average temperatures are still likely to be more than $3^{\circ} \mathrm{C}$ above pre-industrial levels by the end of the century. ${ }^{4}$ With higher levels of heating expected over land mass than over the oceans, accompanied by changes in rainfall patterns, the long term consequences for human health are far reaching. ${ }^{5}$

\section{Safeguarding human health and livelihoods}

The need to protect critically important natural systems is clear. Many of the services provided by nature are important for safeguarding human health and livelihoods. These include the provision of clean water and air, pollination of crops, and medicinal products. The 2019 Intergovernmental Science-Policy Platform on Biodiversity and Ecosystem Services report showed that about 1 million species face extinction without rapid interventions to tackle the drivers of biodiversity loss, such as land use and climate change. ${ }^{6}$ The covid-19 pandemic reminds us that many emerging diseases arise from complex interactions between humans, wildlife, and domestic animals, resulting from changes in land use or food systems. ${ }^{7}$ Marine and terrestrial ecosystems also sequester carbon from the atmosphere and therefore have a vital role in climate mitigation efforts. ${ }^{8}$

The rapid pace of environmental change, especially over recent years, has led to the definition of a new geological epoch, widely known as the Anthropocene, and characterised by the dominance of human activities on Earth systems. ${ }^{9}$
In early 2019, The BMJ issued a call for papers that dealt with the challenges of the Anthropocene for human health and identified opportunities for action. ${ }^{10}$ For example, phasing out fossil fuels could yield major near term health benefits from reduced air pollution, potentially averting millions of premature deaths annually, ${ }^{11}$ as well as reducing greenhouse gas emissions and thus the risks of dangerous climate change. In recent months, several research papers submitted in response to the call have appeared in The BMJ and have discussed the effects on health of predominantly anthropogenic pollutants-including ozone and fine particulate air pollution. ${ }^{12-14}$ We are now fully launching the series by publishing several more articles that emphasise potential ways to reduce the environmental footprint of society and improve public health (https:// www.bmj.com/anthropocene), with more to follow in the next few months. These will include papers on decarbonising the NHS; capitalising on the health (co)benefits of "low carbon" policies in sectors such as energy, housing, transport, and food systems; and the health dividend that could be achieved through more sustainable cities.

\section{Zero emissions target}

The UK parliament has declared a climate emergency, and the Committee on Climate Change recommends a target of net zero emissions by $2050,{ }^{15}$ but it remains unclear how complete decarbonisation can be achieved in practice. Furthermore, it remains uncertain how "emission leakage" (such as replacing UK goods and services with carbon intensive alternatives from countries with lower ambitions for emission reduction) can be avoided. On a global scale the challenges are deeply concerning, with the US planning to leave the Paris agreement and many countries seeming reluctant to act decisively and expeditiously.

On biodiversity loss and other issues that typically receive less attention, political will also is lacking for timely action at scale. For these reasons health professionals have a responsibility to act locally, nationally, and internationally-both as individuals and through their professional bodies-taking a leading role in supporting the implementation of policies that will protect health and tackle the pressing challenges of the Anthropocene.
With health services accountable for about $4.4 \%$ of total greenhouse gas emissions globally (6.3\% for the NHS and Public Health England in the UK), ${ }^{16}$ we clearly need simultaneous transformational change in other sectors-such as energy, food, housing and transport-to make a meaningful contribution to protecting health. This will make the leading role of health professionals in tackling these issues even more pivotal for public health impact.

We hope that this series will provoke debate and discussion, and stimulate more inquiry in this critical area, especially with a focus on solutions. However, there is much more to be done. In November this year the 26th Conference of the Parties (COP) is scheduled to be hosted in Glasgow. ${ }^{17}$ This will be an important opportunity to raise the profile of the interlinkages between climate change and health, and stress the opportunities-in various sectors-to contribute to protecting health in the Anthropocene.

Competing interests: We have read and understood BMJ policy on declaration of interests and declare that PS receives support from the Sustainable and Healthy Food Systems (SHEFS) project supported by the Wellcome Trust's Our Planet, Our Health programme (grant number 205200/Z/16/Z).

Provenance and peer review: Commissioned; externally peer reviewed.

This article is part of a series commissioned by The BMJ. Open access fees are paid by the Wellcome Trust, which had no involvement in external peer review, editing, or the decision to publish.

\section{(c) (1) OPEN ACCESS}

This is an Open Access article distributed in accordance with the terms of the Creative Commons Attribution (CC BY 4.0) license, which permits others to distribute, remix, adapt and build upon this work, for commercial use, provided the original work is properly cited. See: http://creativecommons.org/licenses/by/4.0/.

\section{Check for updates}

1 Leaf A. Potential health effects of global climatic and environmental changes. N Engl I Med 1989;321:157783. doi:10.1056/NEJM198912073212305

2 Haines A. Global warming and health. BMJ 1991;302:669-70. doi:10.1136/ bmj.302.6778.669

3 McMichael AJ. Global warming, ecological disruption and human health: the penny drops. Med J Aust 1991;154:499-501. doi:10.5694/j.1326-5377.1991.tb119437x

4 United Nations Environment Programme. Emissions gap report. UNEP, 2019.

5 Haines A, Ebi K. The imperative for climate action to protect health. N Engl I Med 2019;380:263-73. doi:10.1056/NEJMra1807873 
6 Brondizio E, Settele J, Díaz S, Ngo H. Global assessment report on biodiversity and ecosystem services of the Intergovernmental Science-Policy Platform on Biodiversity and Ecosystem Services. IPBES Secretariat, 2019.

7 Di Marco M, Baker ML, Daszak P, et al. Opinion: sustainable development must account for pandemic risk. Proc Natl Acad Sci U SA 2020;117:3888-92. doi:10.1073/pnas.2001655117

8 Falkowski P, Scholes RJ, Boyle E, et al. The global carbon cycle: a test of our knowledge of earth as a system. Science 2000;290:291-6. doi:10.1126/ science.290.5490.291

9 Steffen W, Persson A, Deutsch L, et al. The Anthropocene: from global change to planetary stewardship. Ambio 2011;40:739-61. doi:10.1007/ s13280-011-0185-x
10 Haines A, Scheelbeek P, Abbasi K. Challenges for health in the Anthropocene epoch. BM/ 2019;364:1460. doi:10.1136/bmj.l460

11 Lelieveld J, Klingmüller K, Pozzer A, et al . Effects of fossil fuel and total Anthropogenic emission removal on public health and climate. Proc Natl Acad Sci U S A 2019;116:7192-7. doi:10.1073/pnas.1819989116

12 Vicedo-Cabrera AM, Sera F, Liu C, et al. Short term association between ozone and mortality: global two stage time series study in 406 locations in 20 countries. BMJ 2020;368:m108. doi:10.1136/bmj.m108

13 Huang $\mathrm{K}$, Liang $\mathrm{F}$, Yang $\mathrm{X}$, et al. Long term exposure to ambient fine particulate matter and incidence of stroke: prospective cohort study from the China-PAR project. BMJ 2019;367:16720. doi:10.1136/bmj.16720

14 Tian Y, Liu H, Wu Y, et al. Association between ambient fine particulate pollution and hospital admissions for cause specific cardiovascular disease: time series study in 184 major Chinese cities. BMJ 2019;367:16572. doi:10.1136/bmj.l6572

15 Committee on Climate Change. Net zero: the UK's contribution to stopping global warming. 2019.

16 Health Care Without Harm, Arup. Health care's climate footprint. How the health sector contributes to the global climate crisis and opportunities for action. 2019 https://noharm-global.org/documents/health-careclimate-footprint-report.

17 United Nations Framework Convention on Climate Change. United Nations climate change conference 2020. https://www.ukcop26.org/

Cite this as: $B M J$ 2020;368:m1103

http://dx.doi.org/10.1136/bmj.m1103 